\title{
Mystery Case: Bilateral Claude syndrome
}

Jens Witsch, MD, Reshma Narula, MD, Hardik Amin, MD, and Joseph L. Schindler, MD

Neurology ${ }^{\circledR}$ 2019;93:599-600. doi:10.1212/WNL.0000000000008176

Figure MRI of the brain

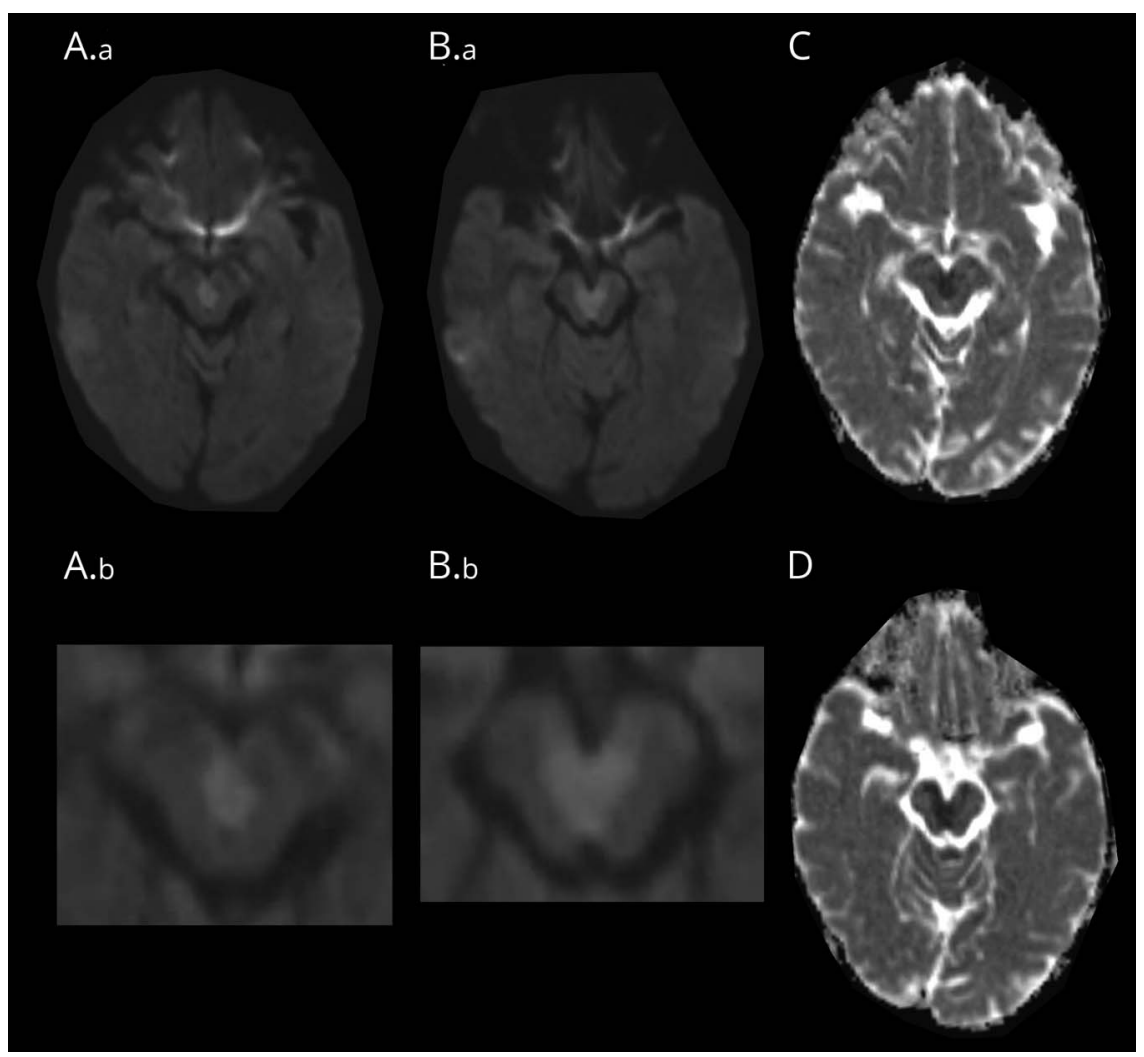

Bilateral paramedian mesencephalic stroke, hyperintense on diffusion-weighted imaging (A.a and B.a, with magnification in A.b and B.b) and hypointense in corresponding areas in the apparent diffusion-coefficient maps (C, D). Lesions involve the third nerves, Edinger-Westphal, and red nuclei, superior cerebellar peduncle, and the reticular activating system, sparing the crura cerebri and tectum.

A 59-year-old man with hypertension, hyperlipidemia, and type 2 diabetes presented with sudden-onset, bilateral ptosis, ataxia, and confusion. Examination showed bilateral ophthalmoparesis sparing minimal adduction and abduction, poorly reactive and dilated pupils, and global ataxia (video). The oculocephalic reflex revealed normal bilateral abduction. Bell phenomenon and convergence were absent. MRI brain showed bilateral paramedian mesencephalic ischemic stroke (figure). Here in a bilateral variant, clinical presentation and imaging closely follow the description of Henri Claude's first case, ${ }^{1}$ where pathologic examination revealed a paramedian midbrain stroke involving the superior cerebellar peduncle, red nucleus, and medial longitudinal fasciculus (MLF). ${ }^{1}$

Third nuclei and MLF lesions likely cause ptosis and vertical and adduction deficits, while injury to fronto-pontine horizontal gaze pathways passing through the midbrain may explain the

\section{Correspondence}

Dr. Schindler

joseph.schindler@yale.edu

\section{MORE ONLINE}

$\checkmark$ Video

\section{Survey and results}

NPub.org/mc9313

From Neurology and Neurosurgery, Division of Stroke and Vascular Neurology (J.L.S.), Department of Neurology (J.W., H.A.), and Department of Vascular Neurology (R.N.), Yale University School of Medicine, New Haven, CT.

Go to Neurology.org/N for full disclosures. Funding information and disclosures deemed relevant by the authors, if any, are provided at the end of the article. 
Table Historical overview of brainstem syndromes

\begin{tabular}{|c|c|c|c|c|c|}
\hline & \multicolumn{5}{|l|}{ Syndrome } \\
\hline & Weber & Claude & Nothnagel & Benedikt & Parinaud \\
\hline $\begin{array}{l}\text { Author describing } \\
\text { syndrome, year of } \\
\text { publication }\end{array}$ & $\begin{array}{l}\text { Hermann David } \\
\text { Weber, } 1863\end{array}$ & Henri Claude, 1912 & $\begin{array}{l}\text { Carl Wilhelm } \\
\text { Hermann } \\
\text { Nothnagel, } 1879\end{array}$ & Moriz Benedikt, 1889 & Henri Parinaud, 1883 \\
\hline $\begin{array}{l}\text { Clinical } \\
\text { presentation }\end{array}$ & $\begin{array}{l}\text { Oculomotor palsy, } \\
\text { contralateral } \\
\text { hemiparesis }\end{array}$ & $\begin{array}{l}\text { Ptosis, ophthalmoplegia, } \\
\text { contralateral } \\
\text { dysdiadochokinesis/ataxia }\end{array}$ & $\begin{array}{l}\text { Bilateral } \\
\text { oculomotor } \\
\text { palsies, ataxia, } \\
\text { nystagmus }\end{array}$ & $\begin{array}{l}\text { Oculomotor palsy, } \\
\text { contralateral } \\
\text { hemiparesis, tremor }\end{array}$ & $\begin{array}{l}\text { Paralysis of upward } \\
\text { gaze and } \\
\text { accommodation, fixed } \\
\text { pupils }\end{array}$ \\
\hline $\begin{array}{l}\text { Anatomical } \\
\text { structures involved }\end{array}$ & $\begin{array}{l}\text { Third nerve nucleus, } \\
\text { corticospinal tract } \\
\text { (crus cerebri) }\end{array}$ & $\begin{array}{l}\text { Third nerve fascicle, red } \\
\text { nucleus, superior } \\
\text { cerebellar peduncle }\end{array}$ & $\begin{array}{l}\text { Superior and } \\
\text { inferior colliculi }\end{array}$ & $\begin{array}{l}\text { Third nerve fascicle, } \\
\text { red nucleus, cerebral } \\
\text { peduncle }\end{array}$ & Dorsal midbrain \\
\hline
\end{tabular}

impaired abduction. ${ }^{2}$ Eponyms of brainstem syndromes are rarely used, because of overlap among the historical descriptions (table).

\section{Author contributions}

J. Witsch: clinical care of the patient, study concept, making of figure, editing of video, writing of the manuscript. R. Narula: clinical care of the patient, making of video, revision of the manuscript. H. Amin: clinical care of the patient, revision of the manuscript. J. Schindler: clinical care of the patient, study concept, acquisition of data, revision of the manuscript.

\section{Study funding}

No targeted funding reported.

\section{Disclosure}

The authors report no disclosures relevant to the manuscript. Go to Neurology.org/N for full disclosures.

\section{References}

1. Liu GT, Crenner CW, Logigian EL, Charness ME, Samuels MA. Midbrain syndromes of Benedikt, Claude, and Nothnagel: setting the record straight. Neurology 1992;42: 1820-1822.

2. Deleu D, Imam YZ, Mesraoua B, Salem KY. Vertical one-and-a-half syndrome with contralesional pseudo-abducens palsy in a patient with thalamomesencephalic stroke. J Neurol Sci 2012;312:180-183.

\section{Mystery Case responses}

The Mystery Case series was initiated by the Neurology ${ }^{\circledR}$ Resident \& Fellow Section to develop the clinical reasoning skills of trainees. Residency programs, medical student preceptors, and individuals were invited to use this Mystery Case as an educational tool. Responses were solicited through a group email sent to the American Academy of Neurology Consortium of Neurology Residents and Fellows and through social media.

Forty-six percent of respondents correctly localized the lesion to the paramedian mesencephalic region. Similarly, $48 \%$ of respondents correctly identified the nuclei involved to cause the particular constellation of symptoms described. Only $8 \%$ of respondents correctly identified large artery disease as the most common cause of mesencephalic stroke. ${ }^{1}$ Four respondents, including 1 medical student, answered all 3 questions correctly.

This mystery case illustrates Claude syndrome, which is a brainstem stroke syndrome characterized by ptosis, ophthalmoplegia, dysdiadochokinesis, and ataxia first described secondary to damage to the third nerve fascicle, red nucleus, and superior cerebellar peduncle. As the authors point out, historical eponyms for brainstem strokes can be confusing due to overlapping clinical presentations. The similarities among syndromes arise from the close anatomical location of these nuclei within the brainstem. Thus, lesion localization within the brainstem requires interpretation of both clinical symptoms and imaging findings combined with detailed knowledge of cranial nerve pathways.

Ariel M. Lyons-Warren, MD, PhD

Baylor College of Medicine, Texas Children's Hospital, Houston

\section{Reference}

1. Kumral E, Bayulkem G, Akyol A, Yunten N, Sirin H, Sagduyu A. Mesencephalic and associated posterior circulation infarcts. Stroke 2002;33:2224-2231. 


\section{Neurology}

\section{Mystery Case: Bilateral Claude syndrome}

Jens Witsch, Reshma Narula, Hardik Amin, et al.

Neurology 2019;93;599-600

DOI 10.1212/WNL.0000000000008176

This information is current as of September 24, 2019

\section{Updated Information \&} Services

\section{References}

Subspecialty Collections

Permissions \& Licensing

Reprints including high resolution figures, can be found at: http://n.neurology.org/content/93/13/599.full

This article cites 3 articles, 2 of which you can access for free at: http://n.neurology.org/content/93/13/599.full\#ref-list-1

This article, along with others on similar topics, appears in the following collection(s):

\section{All Cerebrovascular disease/Stroke}

http://n.neurology.org/cgi/collection/all_cerebrovascular_disease_strok e

\section{Eyelids}

http://n.neurology.org/cgi/collection/eyelids

Gait disorders/ataxia

http://n.neurology.org/cgi/collection/gait_disorders_ataxia

Ocular motility

http://n.neurology.org/cgi/collection/ocular_motility

\section{Tremor}

http://n.neurology.org/cgi/collection/tremor

Information about reproducing this article in parts (figures,tables) or in its entirety can be found online at:

http://www.neurology.org/about/about_the_journal\#permissions

Information about ordering reprints can be found online:

http://n.neurology.org/subscribers/advertise

Neurology ${ }^{\circledR}$ is the official journal of the American Academy of Neurology. Published continuously since 1951, it is now a weekly with 48 issues per year. Copyright () 2019 American Academy of Neurology. All rights reserved. Print ISSN: 0028-3878. Online ISSN: 1526-632X.

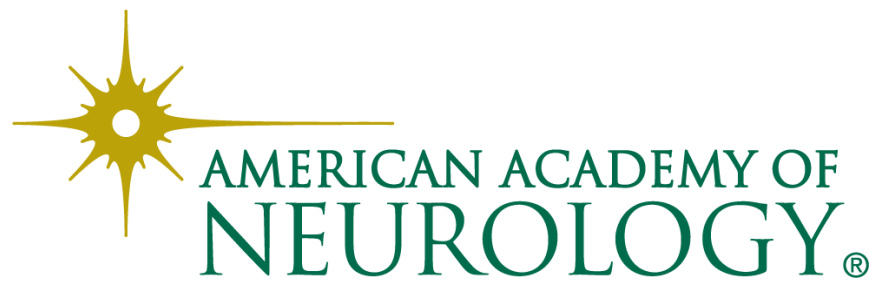

